\title{
KAJIAN PENGUATAN PERAN DIREKTORAT JENDERAL ANGGARAN MELALUI PENERAPAN BUDGET ANALYST
}

\author{
Achmad Fauzan Sirat
}

Email: af.sirat05@gmail.com

Intisari

Kedudukan Chief Financial Officer (CFO) dan Chief Operational Officer (COO) sebagaimana diamanatkan dalam UU Nomor 17/2003 perlu diperjelas demi mempertajam kejelasan pemisahan kewenangan dan tanggung jawab, menguatkan pelaksanaan mekanisme checks and balances, mendorong upaya peningkatan profesionalisme dalam penyelenggaraan tugas pemerintahan, dan mencegah kerancuan baik dalam pelaksanaan peran maupun kedudukan di mata hukum.

DJA sebagai unit pelaksana fungsi CFO dipandang perlu untuk melakukan reposisi peran ke arah yang lebih strategis melalui peningkatan kualitas layanan, penyempurnaan proses bisnis, termasuk mitigasi risiko hukum yang dapat mendemotivasi pegawai yang menyebabkan kondisi vulnerable bagi DJA. Oleh karena itu perlu adanya perubahan mendasar dari yang sebelumnya lebih bersifat administratif menuju ke arah yang lebih strategis.

Tulisan ini dimaksudkan untuk menguraikan perlunya mewujudkan peran DJA sebagai Budget Analyst untuk meningkatkan value for money APBN dan merumuskan langkahlangkah untuk mencapainya.

Kata kunci: budget analyst, Chief Financial Officer (CFO), Chief Operational Officer (COO)

\section{PENDAHULUAN}

\subsection{Latar Belakang}

Sejalan dengan penguatan penerapan sistem penganggaran berbasis kinerja, perlu lebih diperjelas kedudukan Chief Financial Officer (CFO) dan Chief Operational Officer (COO) sebagaimana diamanatkan dalam UU Nomor 17/2003 tentang Keuangan Negara. Kejelasan kedudukan tersebut akan berdampak pada hal-hal sebagai berikut: (1) mempertajam kejelasan pemisahan kewenangan dan tanggung jawab, (2) menguatkan pelaksanaan mekanisme checks and balances, (3) mendorong upaya peningkatan profesionalisme dalam penyelenggaraan tugas pemerintahan, dan dengan demikian (4) Tidak lagi ada kerancuan baik dalam pelaksanaan peran maupun dalam kedudukannya di mata hukum.

Sejalan dengan penguatan peran tersebut, DJA sebagai unit pelaksana fungsi CFO dipandang perlu untuk melakukan reposisi peran ke arah yang lebih strategis, sesuai dengan kedudukan dan tanggungjawabnya dalam sistem penganggaran. Dari aspek tuntutan eksternal, dapat dilihat bahwa sejalan dengan perkembangan reformasi di bidang layanan publik, dimana saat ini stakeholder yang dilayani DJA semakin menuntut peningkatan kualitas layanan yang diberikan oleh Kemenkeu khususnya DJA, yang salah satu aspeknya adalah adanya kesamaan kualitas layanan yang diterima dan adanya kejelasan aturan yang mendasarinya. Tuntuntan eksternal ini perlu direspon dengan langkah-langkah 
untuk mewujudkan perbaikan atas kualitas layanan DJA. Sedangkan dari aspek tuntutan internal dapat dimaklumi bersama bahwa proses bisnis yang telah dibangun selama ini belum sepenuhnya bisa menjadi solusi atas perbaikan kualitas layanan DJA dan oleh karenanya harus dilakukan tanpa henti seiring dengan tuntutan eksternal yang terus meningkat. Hal ini terutama apabila dikaitkan dengan risiko hukum yang dalam pengamatan selama ini dapat mendemotivasi pegawai DJA dalam upaya peningkatan kualitas layanan.

\subsection{Identifikasi Masalah}

Kondisi yang diuraikan di atas menyadarkan kita bahwa ditinjau dari sudut mana pun kedudukan tugas dan fungsi penganggaran yang kita diemban dalam sistem pengelolaan Keuangan Negara sangatlah strategis tetapi vulnerable, yaitu suatu posisi strategis yang penuh ranjau yang bisa menjerat siapa pun dan ranjau tersebut harus dimitigasi agar mampu dijinakkan dengan tanpa menghilangkan nilai peran strategisnya.

\subsection{Tujuan}

Kajian ini bertujuan antara lain:

1. Menguraikan perlunya mewujudkan peran DJA sebagai Budget Analyst, sejalan dengan proses penguatan CFO dalam pengelolaan keuangan Negara.

2. Memperkenalkan langkah-langkah untuk membangun DJA sebagai Budget Analyst.

3. Membuka cakrawala jawaban atas berbagai dimensi dan pertanyaan krusial terkait pembangunan DJA sebagai Budget Analyst, disertai dengan langkah-langkah untuk mencapainya.

\section{METODOLOGI PENELITIAN}

Kajian ini menggunakan metode kualitatif atas suatu permasalahan dengan melakukan analisis melalui review atas literatur.

\section{ASPEK YANG BERPENGARUH}

\subsection{Kerangka Konseptual}

Dari aspek kerangka konseptual, terminologi Chief Operational Officer (COO) dan Chief Financial Officer (CFO) telah dikenal luas dalam sektor privat. Dalam peraturan perundang-undangan RI, terminologi tersebut diadopsi dalam UU Keuangan Negara untuk menggambarkan posisi Menteri Keuangan dan Menteri/Pimpinan Lembaga yang bergerak dalam bidang tertentu. Dalam konteks ini, COO berperan dalam menjalankan fungsi teknis yang menjadi tanggungjawabnya. Sedangkan CFO berperan untuk memastikan sustainabilitas aliran dana guna menjamin eksistensi operasi organisasi. Dari sisi Public Financial Management (PFM) Framework, peran DJA berada dalam irisian dari dua komponen PFM, yaitu sisi belanja (Public Expenditure Management/PEM) dan sisi pendapatan (Public Revenue Management/PRM). Dalam kedudukan demikian, DJA didorong agar mampu memposisikan peran strategisnya dalam: (1) Forecasting revenue/expenditure, (2) Pengaturan penggaran belanja, dan (3) Monitoring evaluasi sebagai dasar forecast tahun-tahun berikutnya. CFO menghadapi constrain dalam menjalankan perannya, meliputi: Di satu sisi, bagaimana belanja 
dapat diupayakan untuk ditekan sedemikian rupa namun dengan tetap memperhatikan kemampuan COO dalam melaksanakan operasionalisasi tugas dan fungsinya. Di sisi lain, pendapatan diupayakan untuk didorong semakin besar namun dengan memperhatikan tax base dan sumber-sumber pendapatan lainnya yang ada karena memaksakan menaikkan tarif pajak tanpa memperhitungkan kemampuan bayar tax payer akan berakibat kontraproduktif terhadap ekonomi makro.

\subsection{Kerangka Hukum dan Konteks Kenegaraan}

Dari aspek kerangka hukum dan konteks kenegaraan, kewenangan Presiden selaku Kepala Pemerintah yang dikuasakan kepada "Pembantunya" sesuai dengan bidang masing-masing, dimana bidang-bidang tersebut disesuaikan dengan prioritas negara dalam mencapai tujuan bernegara. Hal tersebut akan mempertajam pemisahan kewenangan dan tanggung jawab, menguatkan pelaksanaan mekanisme checks and balances, mendorong upaya peningkatan profesionalisme dalam penyelenggaraan tugas pemerintahan. Dalam konteks ini, fungsi COO adalah: (1) Menjamin kelancaran operasi organisasi untuk mencapai tujuan bernegara yang menjadi tanggung jawabnya, (2) Menjaga keberlangsungan operasi dalam mencapai tujuan, dan (3) Melaksanakan sebagian pekerjaan administratif di bidang keuangan. Dalam bidang keuangan, berdasarkan Pasal 6 UU Nomor 17 Tahun 2003 Menteri Keuangan diposisikan selaku Pengelola Fiskal dan Wakil Pemerintah dalam kepemilikan kekayaan negara yang dipisahkan. Terkait dengan pelaksanaan tugasnya, UU Keuangan menggunakan terminologi CFO untuk menggambarkan tugas Menteri Keuangan. Adapun fungsi CFO adalah: (1) Memastikan kebutuhan dana untuk melaksanakan operasi negara terpenuhi, (2) Menjaga ketahanan fiskal sebagai akibat komitmen yang timbul dalam pelaksanaan operasi pemerintah, (3) Melaksanakan fungsi bendahara umum Negara, dan (4) Menjamin sistem keuangan yang ada mampu menciptakan pelaporan yang sesuai.

\subsection{Urgensi Shifting Peran DJA}

Bergulirnya reposisi peran DJA harus dipandang sebagai kristalisasi atau keniscayaan agar DJA mampu beradaptasi secara cepat dan tanggap atas tuntutan eksternal dan internal yang makin berkembang. Reposisi peran DJA tersebut lebih diarahkan pada aspek-aspek yang strategis dalam sistem penganggaran, dan sebagai suatu hal yang krusial mengingat peran DJA dalam pengelolaan keuangan negara belum sepenuhnya dimaknaknai dalam perspektif yang sama oleh para pihak, termasuk didalamnya oleh aparat pengawasan. Salah satu implikasinya adalah hal yang seharusnya menjadi core competency dari DJA dalam pelaksanaannya agak terabaikan. Masih adanya kesalahpahaman dalam memaknai output layanan DJA sebagai bagian awal dari siklus pengelolaan keuangan negara dan upaya untuk memitigasinya mendorong perlunya penyamaan persepsi atas masing-masing peran dalam sistem penganggaran, khususnya dari unsur DJA, $\mathrm{K} / \mathrm{L}$, dan aparat pengawasan. Dengan adanya perspektif yang sama akan berkontribusi pada kejelasan kedudukan, 
kewenangan serta tanggung jawab dalam pelaksanaan keuangan negara sehingga memperkecil gap antara ekspektasi dan kenyataan atas pelayanan DJA.

\subsection{Kendala}

Apabila dicermati dari kondisi pelaksanaan peran DJA existing, dapat dilihat adanya beberapa kendala dalam pelaksanaan perannya, yaitu: (1) tight schedule, too many burden (kurang lebih dua minggu untuk menyelesaikan dokumen), (2) Fokus kerjanya cenderung jangka pendek (fokus telaah pada RKAKL tahun tertentu). (3) Mekanisme benchmarking belum dikembangkan secara memadai (untuk membandingkan antara program/kegiatan/output yang sama), (4) Belum ada upaya konkret untuk pertukaran pengetahuan antar unsur dalam organisasi untuk mencapai tujuan akhir organisasi (knowledge management), (5) Analisis belum mengoptimalkan penggunaan tools data berbasis IT (fokus penelaahan adalah pada TOR/RAB/data dukung, cost of input dII), (6) Analisis mencakup semua berkas sehingga dirasa waktu kurang (karena belum ada risk management procedure yang memadai)

\section{REPOSISI PERAN DJA}

Reposisi peran DJA dimaksud dilakukan dengan merubah cara pandang, mindset dan penekanan tugas yang dilakukan oleh DJA untuk menjami terwujudnya peningkatan value for money APBN, termasuk di dalamnya menyangkut aspek efisiensi alokasi anggaran. Pergeseran tersebut dilakukan terutama dikaitkan dengan 4 (empat) hal yaitu: Pertama, adanya pergeseran lingkup pekerjaan yang sebelumnya lebih banyak bersifat teknis adminstratif menjadi lebih banyak menekankan aspek analitis strategis. Lingkup pekerjaan teknis adminstratif dalam kerangka belanja negara saat ini dilakukan melalui proses pemeriksaan kelengkapan dokumen pendukung pengajuan/penetapan atas suatu alokasi anggaran, menjadi ke arah lingkup pekerjaan yang lebih strategis terutama penetapan target - target kinerja dari suatu kementerian lembaga berbasis kinerja sehingga penelaah anggaran bereposisi dari budget administrator ke budget analyst.

Kedua, perubahan penekanan pekerjaan dari proses pekerjaan yang semula lebih menekankan proporsinya pada proses penelaahan alokasi anggaran menjadi lebih ditekankan pada proses penetapan pagu-pagu anggaran yang dilaksanakan pada tahapan waktu lebih awal, sebelum diajukan ke DPR. Pergeseran dari yang sebelumnya upaya yang dilakukan oleh DJA dalam mendukung efisiensi alokasi terutama dilakukan melalui proses penelaahan, diubah menjadi proses dimana apa yang telah dilakukan tetap berjalan namun peningkatan kualitas pekerjaan justru dilakukan lebih awal pada saat review baseline, diskusi, dan penetapan targettarget kinerja dan biaya yang dibutuhkan baik pada saat penetapan pagu indikatif, pembicaraan trilateral meeting maupun pada saat penetapan pagu anggaran. Konsekuensinya, paradigma yang selama ini berkembang bahwa DJA hanya melakukan exercise pagu khusus yang mengikat perlu di re-definisi kembali.

Ketiga, Pergeseran waktu ke periode yang lebih awal dalam penekanan kualitas pekerjaan yang dilakukan DJA. 
Pelaksanaan kualitas pekerjaan DJA selama ini dilakukan sekitar bulan Juni sebelum anggaran ditetapkan, seiring dengan perubahan penekanan pekerjaan dari budget administrator menjadi budget analyst maka penekanaan kualitas pekerjaan akan dilakukan pada waktu yang lebih awal merujuk proses penetapan target kinerja.

Keempat, Proses penelaahaan yang disederhanakan. Dengan perubahan penekanan pekerjaan maka proses penelaahan yang selama ini menguras tenaga Ditjen Anggaran dengan resiko hukum atas pekerjaan yang demikian besar, maka proses pelaksanaan penelaahannya perlu dilakukan penyederhanaan, yaitu lebih menekankan pada proses penilaian merujuk output dan struktur pembiayaan (model costing). Sedangkan penerapan SBM dalam RKA-K/L yang selama ini menjadi perhatian utama Ditjen Anggaran dalam proses penelaahan, dengan kebijakan terbaru mengenai standar biaya telah digeser menjadi tanggung kementerian/lembaga. Dengan penyederhanaan model dan mekanisme penelaahan tersebut maka diharapkan proses berkenaan menjadi lebih memadai untuk dapat dilakukan secara online. Lebih rinci, arah reposisi adalah dengan meningkatkan orientasi yang semula lebih didominasi oleh pekerjaan-pekerjaan yang bersifat administratif (administratif works) menjadi lebih berorientasi pada pekerjaanpekerjaan yang bersifat analitikal (analist works). Administratif works mencakup: (1) Memastikan legalitas dokumen, Memeriksa kelengkapan dan kesesuaian dokumen pendukung, (3) Kesesuaian item biaya dengan komponen, (4) Kesesuaian item biaya dengan standar biaya, (5) Fokus pekerjaan pada saat penilaian RKAKL yang diajukan oleh K/L. Sedangkan analyst works mencakup: (1) Meneliti relevansi output/sub output dan komponen (lifecycle analysis) dalam review baseline dan new inisiative (sebelum resource envelope),

\section{Gambar 1. Shifting Peran DJA Ke Arah Budget Analist}

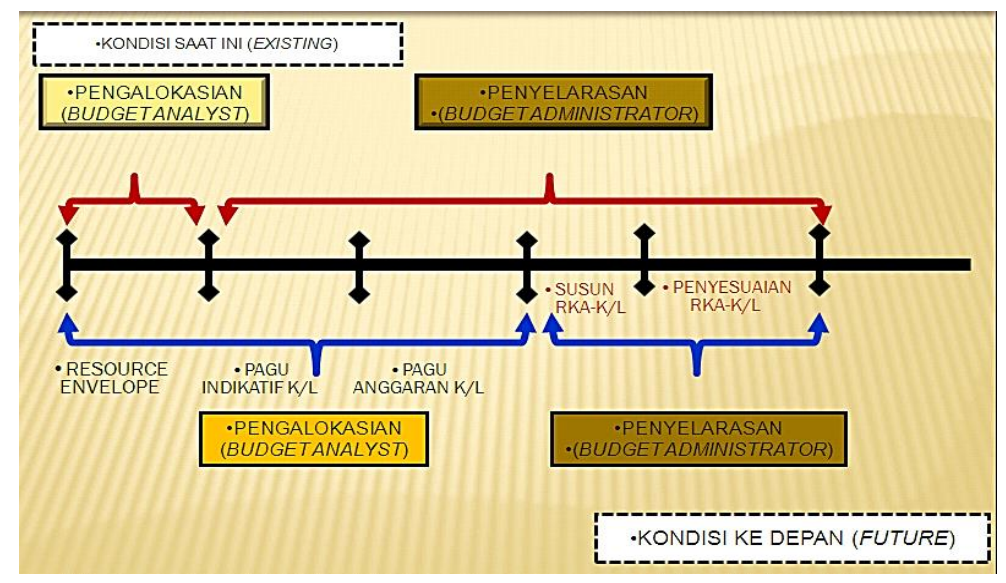

(2) Menilai keberlangsungan output untuk prakiraan maju (forward estimate), (3) Meneliti konsistensi output dengan Renja K/L dan RKP dalam penetapan pagu, (4)
Meneliti konsistensi rumusan output dengan indikator kinerja kegiatannya, (5) Meneliti Struktur Biaya Organisasi berdasarkan info best practice yang ada 
(benchmarking), (6) Fokus pekerjaan pada saat exercise penetapan pagu K/L.

Gambar 2. Konsekuensi Shifting Peran DJA

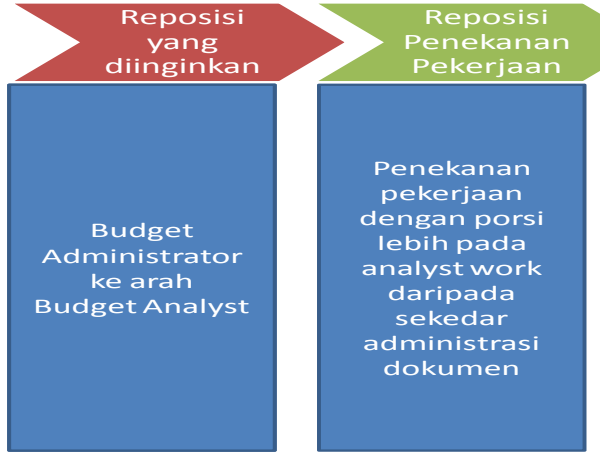

\section{LANGKAH-LANGKAH MEWUJUDKAN}

\section{BUDGET ANALYST}

\subsection{Pilar Budget Analyst}

Beberapa hal yang menjadi faktor kunci keberhasilan dari reposisi peran DJA, yaitu: (1) Definisi Budget Analyst dalam mendukung peran DJA, terutama terkait dengan perlunya kesepakatan atas definisi Budget Analyst dalam peran DJA (hal ini termasuk lingkup pekerjaan dan tanggung jawab, serta analisis yang dilakukan), (2) Reformulasi Proses Bisnis, terutama terkait perlunya menilai proses bisnis yang ada serta menyesuaikan proses tersebut guna mendukung pencapaian tugas dan fungsi Budget Analyst, (3) Penguatan Regulasi,

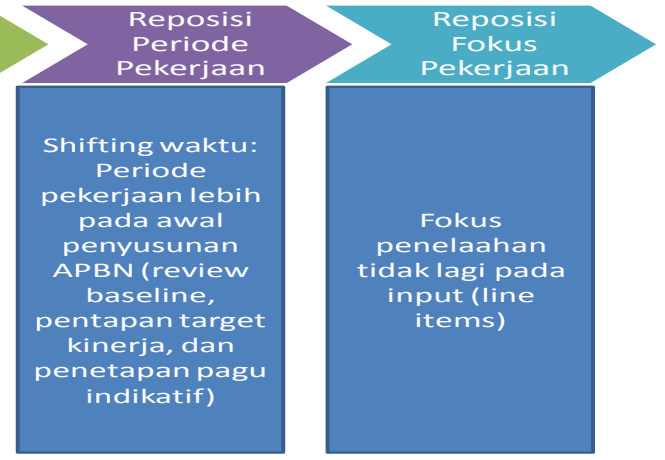

terutama diarahkan untuk memperjelas tata kerja serta tanggung jawab Budget Analyst, (4) Penguatan Instrumen Analysis, dimana seorang budget analyst perlu dilengkapi dengan instrumen-instrumen analisis (kebutuhan, efektifitas, dan efisiensi), (5) Dukungan IT, dimana IT diharapkan dapat menunjang analisis yang lebih memadai dalam proses pengambilan keputusan, dan (6) Penyiapan SDM, terutama memandang perlunya perubahan mindset sesuai dengan formulasi proses bisnis yang baru dan pengembangan kapasitas melalui edukasi serta training diarahkan kepada pembentukan Budget Analsyt.

Gambar 3. Pilar untuk Membangun Budget Analyst 


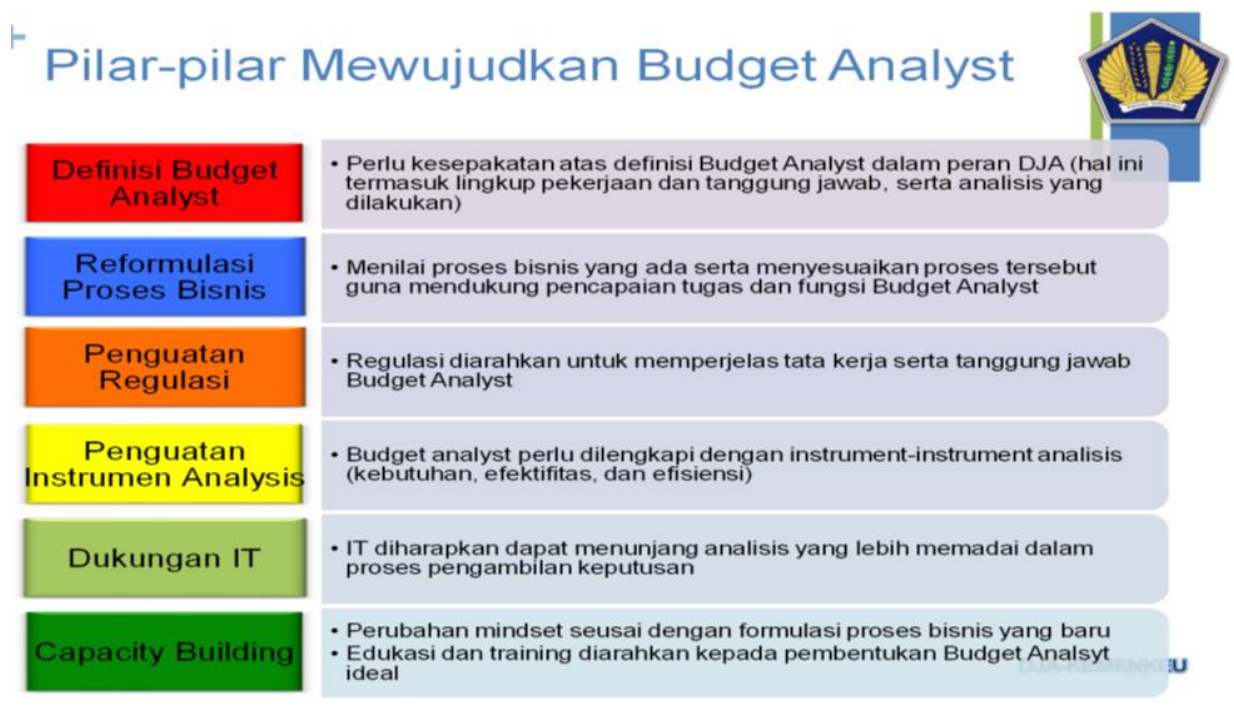

\subsection{Definisi Budget Analyst}

Arah Analisis dan Fungsi Analyst. Dalam konteks pengelolaan keuangan negara, analisis ditujukan pada tercapainya tujuan pengelolaan keuangan negara dengan tetap mengedepankan efisiensi \& efektifitas, serta memastikan stabilitas keuangan negara (budget constraint). Dengan demikian, Budget Analyst menjalankan fungsi: (1) Memproyeksikan Belanja dan Pendapatan (expenditure and revenue forecast), (2) Meningkatkan kualitas Belanja Negara (Spending Quality Improvement), (3) Memonitor dan mengevaluasi Anggaran sebagai bahan untuk perencanaan tahun-tahun berikutnya (monitoring and evaluation). Indikator Kinerja yang dimungkinkan. Terdapat tiga indikator kinerja seorang budget analyst, yaitu: Pertama, Kualitas Forecasting, yang terdiri dari: (1) Ketepatan Jumlah Alokasi (persentase terealisasi), (2) Perubahan Alokasi (berapa kali revisi atas alokasi dilakukan), dan (3) Ketepatan proyeksi ke masa mendatang . Kedua, Kualitas Spending yang terdiri dari: (1) Alokasi tidak ada kendala dalam pelaksanaan (efektif),
(2) Cara yang dilakukan telah memperhatikan efisiensi kegiatan. Ketiga, Kualitas Monitoring dan Evaluasi, yang terdiri dari: (1) Program berjalan sesuai kinerja yang dijanjikan, dan (2) Perbaikan yang dilakukan atas alokasi yang ada.

Pendefinisian budget analyst ini harus dimaknai sebagai keutuhan keseluruhan struktur dan fungsi DJA, yang terdiri dari kesatuan antara jabatan structural dan fungsional untuk menjalankan peran strategis DJA dalam meningkatkan value for money APBN.

\subsection{Penguatan Regulasi}

Check list atas Kondisi Existing. Beberapa pertanyaan yang perlu dikonfirmasi atas kondisi exsisting regulasi yang ada meliputi: (1) Bagaimana proses analisis anggaran saat ini?, (2) Bagian mana yang perlu ditambah, diperkuat, disederhanakan atau dihilangkan?, (3) bagaimana proses analisis anggaran mendatang?, (3) Apakah dengan proses yang baru masalah yang lama akan timbul?, dan (4) Apakah dengan proses yang baru tanggung jawab Analis akan berubah?. Dengan pengutan regulasi ini diharapkan agar pencapaian kinerja DJA 
dalam meningkatkan value for money APBN tersebut dapat dilakukan secara lebih sederhana (simplification) dan fleksibel dengan tetap menjaga akuntabilitas.

Bentuk Regulasi. Perlu dilakukan invetarisasi aturan yang berlaku lebih dari satu tahun (regelling) dan aturan yang bersifat tahunan (beschikking). Pengaturan Regelling bertujuan menjadi fondasi yang kuat dalam sistem penganggaran. Kunci utama pengaturan ini adalah agar konsistensi sistem penganggaran dari tahun ke tahun dapat terjaga. Sedangkan pengaturan Beschikking bertujuan memberikan pengaturan yang bersifat tahunan.

\subsection{Penguatan Instrumen Analisis}

Analisis yang Dimungkinkan. Analisis yang dimungkinkan guna mendukung budget analyst, meliputi: (1) Cost Analysis, sebagai alat analisis untuk menilai kewajaran biaya dan alat untuk membandingkan harga output dalam RKAK/L tahun sebelumnya (tahun berjalan) dengan harga output dalam RKAK/L tahun yang diusulkan, membandingkan harga output yang sama yang diterapkan di wilayah berbeda, atau pun untuk membandingkan harga output yang sejenis yang diterapkan di K/L berbeda. (2) Cost and Benefit Analysis untuk menilai perlunya suatu kegiatan, khususnya untuk menganalisis output baru dan output yang sudah ada tetapi terdapat perubahan biaya. (3) Lifecycle Analysis untuk menilai implikasi biaya baik dalam tahun berkenaan maupun di masa yang akan datang, (4) Performance Measurement Analysis untuk menilai kesesuaian penetapan indikator kinerja dengan capaian yang diharapkan. Hal yang terpenting dalam analisis adalah Budget Analyst dapat menggunakan waktunya lebih banyak mengolah data menjadi informasi yang berguna untuk penganggaran.

Pengembangan Indikator Kinerja, financial dan non-financial indicators. Pengembangan indikator selayaknya ditujukan untuk Financial indicator dan Non-Financial Indicator. Pada sektor privat yang berkembang adalah Financial Measure terlebih dahulu, kemudian pada perkembangannya berlanjut pada nonfinancial measure. Berdasarkan hal tersebut arah pengembangan yang sama bisa diduplikasi dalam sistem penganggaran. Pengembangan indikator kinerja ini harus dikaitkan dengan pengembangan arsitektur kinerja anggaran berbasis Logic Model.

Pengembangan Standar Biaya. Menentukan aturan dasar biaya (asumsiasumsi dasar dalam merancang suatu kegiatan) yang diejawantahkan dalam: (1) Menentukan SBM sebagai alat efisiensi pada level input, (2) Memperjelas norma dasar biaya sebagai pedoman penganggaran dan konsukuensinya dalam pelaksanaan, (3) Menyusun instrumeninstrumen analisis terkait dengan efisiensi, yang diejawantahkan dalam, (4) Menguatkan peran SBK sebagai alat benchmark atas output-output sejenis, (5) Memformulasi standar struktur biaya sebagai alat analisis alokasi anggaran, (6) Memformulasikan penyusunan indeksasi dan struktur biaya guna menjamin kualitas KPJM di tataran output, (7) Memberikan pandangan "Birds' Eye" atas suatu permasalahan yang sama. 
Optimalisasi Hasil Monev. Sebagaimana timeframe analisis budget analyst, hasil monev perlu dioptimalkan dengan wujud pengembangan sub sistem penganggaran, yakni indikator kinerja dan standar biaya. Pada dasarnya perbaikan terus menerus atas sub sistem tersebut diarahkan pada ketajaman penilaian atas kinerja yang dicapai. Penguatan peran monev dimaksukan untuk menilai sampai sejauhmana yang telah direncanakan dapat dicapai (prove) dan untuk memberikan feed-back perbaikan dalam proses alokasi pada tahun berikutnya (improve).

\subsection{Dukungan TI}

Inti dari penggunaan data historis penganggaran berbasis $\mathrm{TI}$ adalah untuk mempercepat proses, menghilangkan duplikasi, dan mengurai kerumitan dlm proses penganggaran Penggunaan data berbasis $\mathrm{TI}$ berfungsi untuk menfasilitasi
Budget Analyst dalam melaksanakan proses bisnis yg ada. Tugas utama seorang Budget Analyst adalah melakukan analisis, dimana peran IT merupakan tools utk mempermudah proses analisis. Oleh karena itu TI perlu diberdayakan untuk mendukung peng-aplikasian instrumeninstrumen analisis, karena TI layaknya suatu "black box" untuk menghasilkan suatu output yang diinginkan Untuk mencapai tujuan tersebut, IT hrs didesain secara user friendly sehingga aplikasi tersebut perlu dirancang sebagai add-ins, sehingga tidak ada duplikasi perekaman input, hanya modifikasi tampilan output, sedemikian rupa sehingga Budget Analyst dapat mengoptimalkannya utk proses analisis anggaran $\mathrm{K} / \mathrm{L}$ Langkah yang perlu ditempuh adalah memastikan kondisi pengembangan IT DJA saat ini pada stage yang mana. Secara umum tahapan IT dapat dilihat secara komprehensif sebagai berikut.

\section{Gambar 4. Stages Pembangunan IT}

\begin{tabular}{|c|c|c|c|c|}
\hline $\begin{array}{l}\text { System } \\
\text { Aspects }\end{array}$ & $\begin{array}{l}\text { Stage } 1 \\
\text { System } \\
\text { Broken }\end{array}$ & $\begin{array}{c}\text { Stage } 2 \\
\text { Systems Fin. } \\
\text { Reporting Driven }\end{array}$ & $\begin{array}{c}\text { Stage } 3 \\
\text { Systems Customized } \\
\text { Stand-Alone }\end{array}$ & $\begin{array}{c}\text { Stage } 4 \\
\text { System Integrated }\end{array}$ \\
\hline $\begin{array}{l}\text { Data } \\
\text { Quality }\end{array}$ & $\begin{array}{l}\text { Many errors } \\
\text { Large } \\
\text { Variance }\end{array}$ & $\begin{array}{l}\text { No surprises } \\
\text { Meet audit } \\
\text { standards }\end{array}$ & $\begin{array}{l}\text { Shared Databases } \\
\text { Stand alone system }\end{array}$ & $\begin{array}{l}\text { Fully linked } \\
\text { databases and } \\
\text { system }\end{array}$ \\
\hline $\begin{array}{l}\text { External } \\
\text { Fin. Report }\end{array}$ & inadequate & $\begin{array}{l}\text { Tailored to Fin. } \\
\text { Reporting Needs }\end{array}$ & $\begin{array}{l}\text { Stage } 2 \text { system } \\
\text { maintaned for fin. } \\
\text { Transaction } \\
\text { \&periodic reporting }\end{array}$ & $\begin{array}{l}\text { Financial reporting } \\
\text { system }\end{array}$ \\
\hline $\begin{array}{l}\text { Product/Cu } \\
\text { stomer } \\
\text { Costs }\end{array}$ & inadequate & $\begin{array}{l}\text { Inaccurate } \\
\text { Hidden costs and } \\
\text { profits }\end{array}$ & $\begin{array}{l}\text { PC-based } A B C \text { for } \\
\text { costing activities } \\
\text { products \& cost }\end{array}$ & $\begin{array}{l}\text { Integrated ABM } \\
\text { system }\end{array}$ \\
\hline $\begin{array}{l}\text { Operational } \\
\text { \& Strategic } \\
\text { Control }\end{array}$ & inadequate & $\begin{array}{l}\text { Fin. Feedback } \\
\text { only } \\
\text { Delayed, } \\
\text { aggregate }\end{array}$ & $\begin{array}{l}\text { Kaizen costing: } \\
\text { pseudo profit center, } \\
\text { timely non Fin. } \\
\text { Feedback }\end{array}$ & $\begin{array}{l}\text { Operational \& } \\
\text { strategic } \\
\text { performance } \\
\text { measure system }\end{array}$ \\
\hline
\end{tabular}




\subsection{Penyiapan SDM}

Arah Pengembangan SDM.

Beberapa arah pengembangan SDM untuk mendukung terwujudnya pelaksanaan fungsi Budget Analyst meliputi: (1) Merubah mindset seusai dengan formulasi proses bisnis yang baru, (2) Menyeleraskan kapasitas dan kapabilitas SDM agar sejalan dengan tuntutan penggunaan instrumen analysis dan pengembangan sistem yang ada, (3) Peningkatan Motivasi Pegawai dengan ada balancing antara kompensasi dan risiko, (4) Pola pembinaan SDM yang jelas dalam hal mutasi, promosi, serta pembinaan karier yang menyatu dengan HR Blue Print. Hal ini mendorong ungensi penyelesaian kebijakan profesi budget analyst yang dilengkapi dengan pilar jabatan fungsional budget analyst pada DJA dan sertifikasi budget analyst dari lembaga yang kredibel.

Edukasi dan Training. Beberapa hal yang perlu mendapat perhatian dalam pelaksanaan edukasi dan training para budget analyst meliputi: (1) Perubahan Penekanan Pekerjaan akan berimbas pada perubahan kompetensi yang dibutuhkan, (2) Edukasi dan training selayaknya diarahkan kepada pemenuhan core competency yang diharapkan ada pada setiap budget analyst, (3) Edukasi ditujukan untuk perubahan mindset, knowledge serta sikap, (4) Training ditujukan untuk mengasah skill yang dibutuhkan dalam analisis, terutama diarahkan untuk memberikan sertifikasi kepada Budget Analyst.

Pembinaan Karier. Perlu dirumuskan kedudukan Budget Analyst dalam administrasi kepegawaian (struktural/fungsional). Perlu perumusan pola karier Budget Analyst dalam pelaksanaan pekerjaannya. Perlu kejelasan sistem reward and punishment dalam pelaksanaan tugas dan fungsi Budget Analyst.

Shifting Peran DJA sebagai Budget Analyst ini perlu ditempuh melalui serangkaian tahapan. Tahapan tersebut perlu diawali dengan penyamaan persepsi dan pandangan terkait reposisi peran DJA lebih sebagai Budget Analist, khususnya untuk menjawab beberapa pertanyaan mengenai : (1) Apa yang dimaksud dengan budget analyst, (2) Mengapa dibutuhkan budget analyst, (3) Apa saja ruang lingkup pekerjaan dan tanggung jawab dari budget analyst, (4) Apa saja konsekuensi yang akan diterima dengan pengukuhan peran sebagai analyst, (5) Apa saja yang diperlukan dalam penguatan posisi sebagai budget analyst, dan (6) Apakah dampaknya terhadap proses bisnis yang ada sekarang ini. Selanjutnya, perlu ditempuh langkah-langkah strategis untuk mewujudkan peran DJA sebagai Budget Analyst, sehingga kendala terkait peran DJA (existing) dapat diatasi melalui pondasi penerapan pilar-pilar strategis dalam membangun Budget Analyst.

\section{PENUTUP}

Reposisi peran DJA menjadi Budget Analyst merupakan suatu keniscayaan agar peran strategis DJA untuk meningkatkan value for money APBN dapat diwujudkan. Perubahan tersebut mengarah pada pengembangan DJA menuju core competencies yang diharapkan. Arah pengembangan tersebut harus disertai dengan pengelolaan risiko yang memadai, khususnya mitigasi atas risiko hukum dalam pelaksanaan tugas dan fungsi 
budget analyst. Enam pilar untuk mewujudkan budget analyst harus menjadi komitmen bersama, dirangkum dalam suatu regulasi, dan diwujudkan dalam suatu pelaksanaan yang baik dan konsisten. Langkah-langkah implementasi dari kebijakan ini perlu dimonitor secara ketat agar reposisi yang diharapkan tercapai sesuai harapan. 